\title{
EFFECT OF CHLORELLA AS A BIOFERTILIZER ON GERMINATION OF WHEAT AND BARLEY GRAINS
}

\author{
Odgerel B. ${ }^{1 *}$ and Tserendulam $D .{ }^{1}$
}

1. Microbial Synthesis Laboratory, Institute of General and Experimental Biology, MAS

*corresponding author: e-mail: odgoo22@gmail.com

\begin{abstract}
Most of the agriculture sectors have been dependent heavily on inorganic chemical-based fertilizers, which are harmful for both human health and environment. The utilization of beneficial microbes as a biofertilizer has become major concern in industrial agriculture for their potential role in food safety and sustainable crop production. In this study, we examined the effect of Chlorella on germination of barley and wheat grains. Seeds were germinated in culture medium containing microalga (Chlorella sp. 56) and grown for 3, 6, 9 and 12 days in order to study its effect on growth parameters. In conclusion, Chlorella suspension increased the seed growth compared to those of control (sterilized culture medium) of seed germination. The best treatments were $0.06 \mathrm{~g} / \mathrm{L}$ and $0.23 \mathrm{~g} / \mathrm{L}$ of algal suspension for the root and shoot lengths of barley and wheat seeds, respectively.
\end{abstract}

Keyboards: Chlorella; biofertilizer; germination; barley and wheat grains;

\section{INTRODUCTION}

In order to meet the food demands of a growing world population, agriculture sectors have been increasingly using chemical fertilizer. Chemical fertilizers are mainly a mixture of substances, such as nitrogen, phosphorus and potassium. The excess uses of chemical fertilizers in agriculture are costly and also have various harmful effects [1]. For instance, residual chemicals reach to water bodies through rainwater and cause eutrophication in water bodies. It can also reduce water holding capacity, soil fertility and disparity in soil nutrients, which could further led to unfavorable condition for living microorganisms in soil [2]. In this regard, organic fertilizers and biofertilizers have become alternative sources.

As compared to chemical fertilizers, biofertilizers are eco-friendly and cost effective. Biofertilizers contain various microorganisms that provide all kinds of micro and macroelements via nitrogen fixation, phosphate and potassium solubilization or mineralization, release of plant growth promoting substances, production of antibiotics and biodegradation of organic matter in the soil [3], [4]. When biofertilizers are used continuously for many years, parental inoculums become sufficient for further multiplication [2], hence they participate in nutrient cycling and benefit crop productivity [5]. Main benefits of biofertilizers are 1) cheap source of nutrients; 2) suppliers of 
microelements; 3) suppliers of organic matter; 4) counteracting negative impact of chemical fertilizers; 5) secretion of growth hormone [6]; 6) no adverse effects to ecosystem and 7) longer shelf life [7]Azotobacter species were selected via phenotypic, biochemical and molecular characterisations from different rice fields. Acetylene reduction assay of Azotobacter spp. showed that Azotobacter vinelandii (Az3.

Certain species of microorganisms are widely used in biofertilizers. Among them, benefiting the crop production are Azotobacter, Azospirillium, Acetobacter, cyanobacteria, Azolla, phosphate solubilizing microorganisms, mycorrhizae, Sinorhizobium and plant growth promoting Rhizobacteria [2], [8]. For instance, Some strains of Azotobacter, Azospirillium, Phosphobacter and Rhizobacter can provide significant amount of nitrogen and increase the plant height, number of leaves, stem diameter percentage of seed filling and

\section{MATERIALS AND METHODS}

Plant material. The experimental plants used in this study were seeds of barley and wheat. The wheat seeds were grown in the soil of State farm of Mongolia, and were collected by "Altan Taria" Co.Ltd in September, 2014. While the barley seeds were collected from Altai, Khovd aimag in 2010 and kept at $-4^{\circ} \mathrm{C}$ under dark condition until the experiment.

Algal culture. Microalga (Chlorella sp. 56) strain was obtained from the Culture Collection of Microalgae at Institute of General and Experimental Biology, MAS and was cultivated using standard medium 04 . The final $\mathrm{pH}$ of this medium was 6.8 , after being autoclaved. The culture was grown with a light intensity of 8 Klux provided by cool white fluorescent lamps and a temperature of $25 \pm 2^{\circ} \mathrm{C}$ under illumination regime of $6: 18$ dark and light cycle for a week. Filtered air was let to bubble in the culture vessels to provide aeration and agitation.

Effect of culture media after growth of algal strain on seed germination. In this its dry weight in Helianthus annus [9]. Similar results were also observed in roots of rice [10] this element is usually supplied to the rice crop as the commercially available fertilizer urea. But unfortunately a substantial amount of the urea-N is lost through different mechanisms causing environmental pollution problems. Utilization of biological $\mathrm{N}$ fixation (BNF. In last few decades, some researchers conducted studies on potential uses of green algae as biofertilizers [11]-[16]. Dry biomasses of green algae contain high percentage of macronutrients, considerable amount of micronutrients and amino acids [17], [18].

The aim of this work was to study the effect of Chlorella sp. 56 strain on germination of barley and wheat grains and to determine any potential application of Chlorella microalga as a biofertilizer in order to improve the yield quality and productivity and avoid environmental pollution.

experiment, algal suspensions were collected at $3 \mathrm{~d}, 6$ th, 9th and 12th days and were examined for both cell count and dry biomass yield.

Determination of cell number and biomass content of alga. Growth of Chlorella sp. 56 strain was measured in terms of cell number and dry weight biomass. Cell concentrations were counted using a hemocytometer. Data were given as cell per $\mathrm{mL}$. The determination of dry biomass yield was performed using Vladimirova's method [19]. The culture suspensions were mixed well prior to the sampling. $5 \mathrm{~mL}$ of samples were collected in weighing bottles thrice weekly. The bottles were dried at $105^{\circ} \mathrm{C}$ oven until the weight of the bottles become constant. The dry biomass yield was determined by using following formula:

$$
D W(g / L)=(a-b) / Y * 200
$$

Where: $a$ - the total weight of weighing bottle containing dried biomass ( $g$ )

$$
\begin{aligned}
& b \text {-weight of the weighing bottle }(g) \\
& Y \text {-sample volume taken }(m L)
\end{aligned}
$$

The data were given as $\mathrm{mg} / \mathrm{g}$ algae mass. 
Treatment of barley and wheat seeds. Seeds were surface sterilized with $30 \%$ sodium hypochlorite for $8 \mathrm{~min}$, then rinsed with distilled water several times before germination. The seeds of wheat and barley were placed in petri dishes containing $3 \mathrm{~mL}$ of sterilized culture medium as a control. $2 \mathrm{ml}$ of algal suspension was collected after growing the algal strain for 3, 6, 9 and 12 days, and added to each petri dish containing barley and wheat seeds. Petri dishes were maintained in thermostat at temperature of $18 \pm 2^{\circ} \mathrm{C}$ under the light regime of 8:16 light and dark for a week. At the end of the experiment, lengths of shoots and roots per plant were determined.

Statistic analysis. All experimental analyses were performed in triplicate and the mean values were calculated. The data were subjected to analysis of variance and Student's t-test and F-test were used to assess differences between means.

\section{RESULTS}

Growth parameters (cell counts and dry biomass yield) of alga. The growth of Chlorella sp. 56 strain was followed after 12 days. The cell counts and dry weight were recorded at 3 , 6,9 , and 12 days.

\section{Table 1.}

Concentrations of algal suspension used in this experiment.

\begin{tabular}{ccccc}
\hline Days & 3 & 6 & 9 & 12 \\
\hline Dry biomass $(\mathrm{g} / \mathrm{L})$ & 0.06 & 0.14 & 0.23 & 0.33 \\
Cell counts $($ cells $/ \mathrm{ml})$ & $1.5^{*} 10^{6}$ & $5.3 * 10^{6}$ & $6.8^{*} 10^{6}$ & $11.8^{*} 10^{6}$ \\
\hline
\end{tabular}

As shown in Table 1 , the dry biomass yields were $0.06 \mathrm{~g} / \mathrm{L}, 0.14 \mathrm{~g} / \mathrm{L}, 0.23 \mathrm{~g} / \mathrm{L}$ and $0.33 \mathrm{~g} / \mathrm{L}$ at day 3, 6, 9 and 12, respectively. Meanwhile, the cell counts were $1.5,5.3,6.8$ and 11.8 million cell $/ \mathrm{mL}$ in respective algal suspensions.

Seed germination and seedling growth of

\section{barley and wheat plants.}

The results of growth parameters obtained for the germination of barley and wheat seeds subjected to culture media after growth of Chlorella sp. 56 strain for 3, 6, 9, and 12 days treatments are given in Figure 1 and 2.



Figure 1. Effect of culture medium containing Chlorella sp. 56 grown for 3, 6, 9 and 12 days on growth parameters of seeds germination of barley plant. 
As shown in Figure 1, the growth of barley shoot at day 3 was close to that of control. Also, the lengths of both shoot and root were shorter than that of control at days 6,9 and 12 . However, the length of root at day 3 was $25 \%$ longer than that of control.

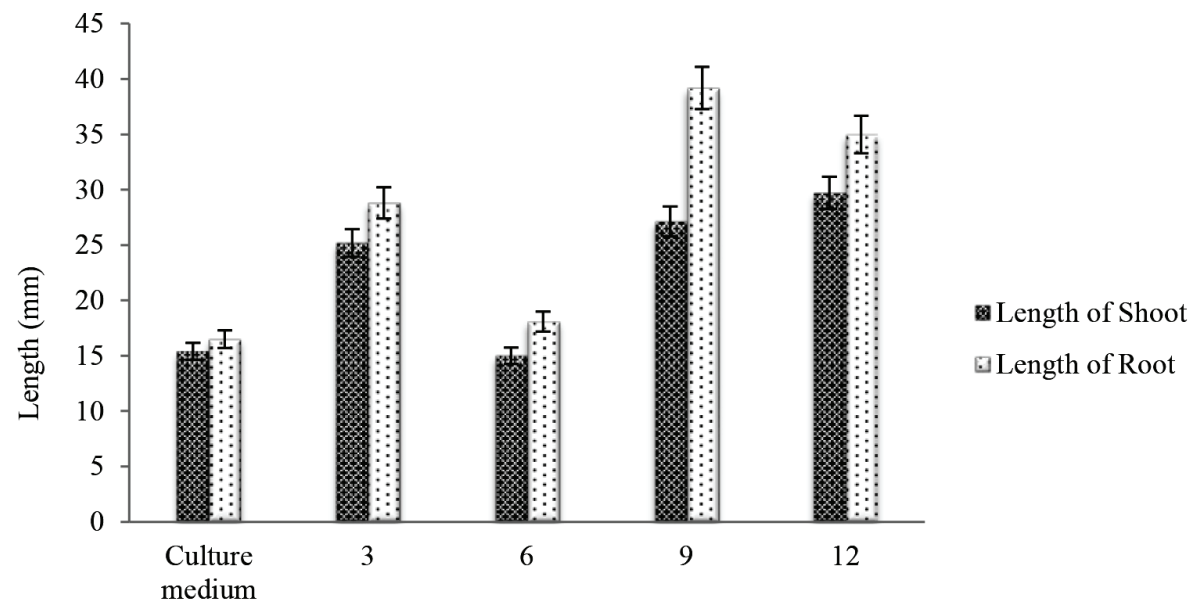

Cultured days of Chlorella sp. 56

Figure 2. Effect of culture medium containing Chlorella sp. 56 grown for 3, 6, 9 and 12 days on growth parameters of seeds germination of wheat plant.

It is shown in Figure 2, that the lengths of both wheat shoot and root were much longer at days 3, 9 and 12 as compared to control. The lengths of shoot and root were close to that of control at day 6 . The highest length of shoot was obtained at day 12 , which was 1.9 times higher than that of control. However, the highest length of root was observed at day 9 and it was 2.4 times higher than that of control.

\section{DISCUSSION}

The application of microalgal suspension led to increase significantly the wheat seed germination under lab condition. This idea was previously confirmed by Abd El-Bake, (2008) who found that, splaying wheat cultivated with microalgae extracts obtained from Chlorella sp. led to keep good growth and yield of wheat compared to those received recommended dose of chemical nitrogen. Similar trends were found by Adam (1999) [20]. Furthermore, increase in lengths of shoot and root resulted

\section{CONCLUSIONS}

It can be concluded that Chlorella suspension can enhance the germinations of wheat and barley seeds. Chlorella sp. 56 algal from the floating of plant seeds in algal suspension. The stimulatory effects of alga as bio-fertilizer on some growth parameters of lettuce was obtained in the study results by Rani and Sathiamoorthy (1997) [21]. Similar results were also obtained by Mahmoud and Amara (2000), in which all treatments significantly increased plant growth parameters compared to untreated plant [22]. Moreover, enhancement in the growth parameter leads to improved crop productivity [22]-[26]. suspensions of $0.06 \mathrm{~g} / \mathrm{L}$ and $0.23 \mathrm{~g} / \mathrm{L}$ can improve the root and shoot lengths of barley and wheat seeds, respectively. 


\section{Acknowledgements}

The authors thank B. Oyunsuvd, a laboratory assistant at Altan Taria Co. Ltd., for kindly providing the samples of wheat seeds.

\section{REFERENCES}

[1] V. B. Santos, A. S. F. Araujo, L. F. C. Leite, L. A. P. L. Nunes, and W. J. Melo, "Soil mirobial biomass and organic matter fractions during transition from conventional to organic farming systems," Geoderma, vol. 170, pp. 227-231, 2012.

[2] M. M. A. Youssef and M. F. M. Eissa, "Biofertilizers and their role in management of plant parasitic nematodes. A review," vol. 5, no. 1, pp. 1-6, 2014.

[3] R. K. Sinha, D. Valani, K. Chauhan, and S. Agarwal, "Embarking on a second green revolution for sustainable agriculture by vermiculture biotechnology using earthworms : Reviving the dreams of Sir Charles Darwin," J. Adv. Biotechnol. Sustain. Dev., vol. 2, no. August, pp. 113-128, 2010.

[4] A. K. Goel, R. D. S. Laura, P. G. Anuradha, and A. Goel, "Use of biofertilizers: potential, constraints abd future strategies review," Int. J. Trop. Agric., vol. 17, pp. 1-8, 1999.

[5] J. S. Singh, V. C. Pandey, and D. P. Singh, "Efficient soil microorganisms: a new dimension for sustainable agriculture and environmental development," Agric. Ecosyst. Environ., vol. 140, no. 3-4, pp. 339-353, 2011.

[6] V. Gaur, "Biofertilizer - Necessity for Sustainability," J. Adv. Dev., vol. 1, pp. 7-8, 2010.

[7] R. K. Sahoo, M. W. Ansari, T. K. Dangar, S. Mohanty, and N. Tuteja, "Phenotypic and molecular characterisation of efficient nitrogen-fixing Azotobacter strains from rice fields for crop improvement.," Protoplasma, vol. 251, no. 3, pp. 511-23, 2014.

[8] D. M. Hegde, B. S. Dwivedi, and S. N. S. Babu, "Bio-fertilizers for cereal production in India," Ind. J. Agric. Sci., vol. 69, pp. 73-83, 1999.

[9] R. Dhandapani and T. Nadu, "Effect of biofertilizers on th growth of Helianthus annuus," Int. J. Plant, Anim. Environ. Sci., vol. 2, no. 4, pp. 143-147, 2012.

[10] A. T. M. A. Choudhury and I. R. Kennedy, "Prospects and potentials for systems of biological nitrogen fixation in sustainable rice production," Biol. Fertil. Soils, vol. 39, no. 4, pp. 219 227, 2004.

[11] R. Vig, A. Dobos, K. Molnar, and J. Nagy, "The efficiency of natural foliar fertilizers," Idojaras, vol. 116, no. 1, pp. 53-64, 2012.

[12] T. Bileva, "Influence of Green Algae Chlorella vulgaris on Infested with Xiphinema index Grape Seedlings,” J. Earth Sci. Clim. Change, vol. 04, no. 02, pp. 2-4, 2013.

[13] E. a. Abd El Moniem and a. S. E. Abd-Allah, "Effect of Green Alga Cells Extract as Foliar Spray on Vegetative Growth, Yield and Berries Quality of Superior Grapevines.," Am. J. Agric. Environ. Sci., vol. 4, no. 4, pp. 427-433, 2008.

[14] M. Grzesik and Z. Romanowska-Duda, "Ability of Cyanobacteria and green algae to improve metabolic activity and development of willow plants, " Polish J. Environ. Stud., vol. 24, no. 3, pp. 1003-1012, 2015.

[15] A. Dubey and D. Dubey, "Evaluation of Cost Effective Organic Fertilizers," 2010.

[16] F. A. Faheed and Z. Abd-El Fattah, "Effect of Chlorella vulgaris as Bio-fertilizer on Growth Parameters and Metabolic Aspects of Lettuce Plant," J. Agric. Soc. Sci., vol. 4, no. 1965, pp. 165-169, 2008.

[17] M. S. Mahmoud, "Nutritional status and growth of maize plants as affected by green microalgae as soil additives," J. Biol. Sci., vol. 1, pp. 475-479, 2001.

[18] M. M. El-Fouly, F. E. Abdalla, and M. M. Shaaban, "Multipurpose large scale production of microalgae biomass in Egypt," Proc. 1st Egypt. Etalian Symp. Biotechnol., vol. 21-23, pp. 305-314, 1992.

[19] L. A. Sirenko, Nazvanie: Metody fiziologo-biokhimicheskogo issledovaniya vodorosley v 
gidrobiologicheskoy praktike. Kiev: Naukova dumka, 1975.

[20] M. S. Adam, "The promotive effect of the cyanobacterium Nostoc muscorum on the growth of some crop plants, " Microbiol. polinica, vol. 48, pp. 163-171, 1999.

[21] M. S. A. Rani and S. Sathiamoorthy, "Effect of organic and bio-fertilizers on root enzyme activity, nematode, total biomass and growth enhancement of Papaya," South India Hortic., vol. 45, pp. 217-223, 1997.

[22] H. A. F. Mahmoud and M. A. T. Amara, "Response of tomato to biological and mineral fertilizers under calcareous soil conditions," Bull. Factorial Agric., no. 51, pp. 151-174, 2000.

[23] D. C. Ghosh and M. Mohiuddin, "Response of summer sesame (Sesamum indicum) to biofertilizer and growth regulator," Agric. Sci. Dig., vol. 20, pp. 90-92, 2000.

[24] A. C. Mehta, D. D. Malavia, B. B. Kaneria, and V. D. Khanpara, "Effect of phosphatic bio-fertilizers in conjunction with organic and inorganic fertilizers on growth and yield of groundnut (Arachis hypogaea), " Indian J. Agron., vol. 40, pp. 709-710, 1995.

[25] J. Snehal, N. A. Zende, and S. Joshi, "Bio-fertilizers and organic manures in sugarcane spaced transplanting method," in Proceedings of the 60th Annual Conference of the Sugar Technology, Shemla, India, 1998, pp. 105-113.

[26] A. K. Das, M. K. Bera, and M. Mohiuddin, "Effect of different yield attributes on the productivity of wheat as influenced by growth regulators and bio-fertilizers, "Environ. Ecol., vol. 19, pp. 145-148, 2001. 